\title{
Reverse transcriptase loop-mediated isothermal amplification assay for infectious hematopoietic necrosis virus in Oncorhynchus keta
}

\author{
Rungkarn Suebsing ${ }^{1}$, Chan-Hyeok Jeon ${ }^{1}$, Myung-Joo Oh $^{2}$, Jeong-Ho Kim ${ }^{1, *}$ \\ ${ }^{1}$ Faculty of Marine Bioscience \& Technology, Gangneung-Wonju National University, Gangneung 210-702, South Korea \\ ${ }^{2}$ Department of Aqualife Medicine, Chonnam National University, Yosu 550-749, South Korea
}

\begin{abstract}
A reverse transcriptase loop-mediated isothermal amplification (RT-LAMP) assay was developed for detecting infectious hematopoietic necrosis virus (IHNV) from chum salmon Oncorhynchus keta in South Korea with high specificity, sensitivity and rapidity. A set of 6 IHNV-specific primers was designed, based on the G-protein sequence of IHNV (PRT strain), recognizing 8 distinct sequences of the target RNA. The assay was optimized to detect IHNV at $63^{\circ} \mathrm{C}$ for $30 \mathrm{~min}$. The limit of detection was $0.01 \mathrm{fg}$ of RNA extracted from IHNV-infected CHSE-214 cells, compared with $1.0 \mathrm{fg}$ for nested RT-PCR. The applicability of this RT-LAMP assay was further tested by comparison with nested RT-PCR using field samples. Of 473 samples tested, 191 samples (40.38\%) were IHNVpositive by RT-LAMP, whereas 162 samples (34.25\%) were IHNV-positive by nested RT-PCR. These results indicate that, because of its high sensitivity and rapidity, the RT-LAMP assay is useful for early diagnosis of IHN.
\end{abstract}

KEY WORDS: RT-LAMP $\cdot \mathrm{IHNV} \cdot$ Chum salmon $\cdot$ Oncorhynchus keta

Resale or republication not permitted without written consent of the publisher

\section{INTRODUCTION}

Infectious hematopoietic necrosis virus (IHNV) is a member of the genus Novirhabdovirus (family Rhabdoviridae) and has a linear single-strand, negativesense RNA genome of $\sim 11000$ nucleotides (nt). The IHNV genome consists of 6 genes encoding the nucleocapsid protein $(\mathrm{N})$, phosphoprotein $(\mathrm{P})$, matrix protein (M), glycoprotein (G), nonvirion protein (NV) and polymerase (L) (Kurath et al. 1985, Morzunov et al. 1995). The $G, N$ and $L$ genes have been employed for investigating IHNV evolution, diversity and phylogenetic relationships among isolates worldwide (Garver et al. 2003, Kim et al. 2003, 2007, Enzmann et al. 2005, Nishizawa et al. 2006)

IHNV was first reported from fish hatcheries in Oregon and Washington, USA, in the 1950s (Rucker et al. 1953) and its worldwide distribution is thought to be due to movement of contaminated fish and fish eggs to Asian and European countries (Nishizawa et al. 2006, Kim et al. 2007). Consequently, the virus has been reported in various countries including Japan (Sano 1976), France (Baudin-Laurencin 1987), Italy (Bovo et al. 1987) and Germany (Enzmann et al. 1992). However, there was no IHNV occurrence in Korea until 1991, when the virus was recorded in juvenile rainbow trout Oncorhynchus mykiss and masu salmon $O$. masou in Kangwon Province, South Korea (Park et al. 1993). Since then, a series of IHN outbreaks have occurred in rainbow trout farms in various parts of Korea. In 2003, Korean rainbow trout farms experienced economic losses because of IHN in both juvenile and market-size fish (Kim et al. 2003). Three major virus genogroups designated $\mathrm{U}, \mathrm{M}$ and $\mathrm{L}$, indicating their correlation with the upper, middle and lower geographic areas in the Pacific Northwest of North America, were proposed (Garver et al. 2003, Kurath et al. 2003). More recently, 2 additional genogroups for European and Japanese (JRt) isolates were proposed (Enzmann et al. 2005, Nishizawa et al. 2006).

There are several technologies for detecting IHNV (Kim et al. 2001), including the conventional RT-PCR 
method. However, nested RT-PCR methods require a second amplification step that is prone to contamination. To solve these problems, the loop-mediated isothermal amplification (LAMP) assay was investigated as an alternative. LAMP was originally developed by Notomi et al. (2000) and can amplify very low numbers of target sequences to $10^{9}$ copies under isothermal conditions within $1 \mathrm{~h}$. This method depends on auto-cycling strand displacement DNA synthesis by the Bst DNA polymerase large fragment with high strand displacement activity, and a set of 2 specially designed inner primers and 2 outer primers. LAMP is highly specific because the target sequences are detected by 6 independent primers in the initial stage, followed by 4 independent primers in the later stages of the LAMP reaction. LAMP is also applicable for RNA detection by using a reverse transcriptase (RT) together with a DNA polymerase (Notomi et al. 2000). This technique can be carried out under isothermal conditions, which can be simply achieved with a water bath or a heating block. Expensive thermal cyclers used for PCR are not required (Notomi et al. 2000).

In the present study, an RT-LAMP assay was developed for detecting IHNV from wild adult chum salmon Oncorhynchus keta and artificially hatched fry in Korea. A set of 6 LAMP-specific primers was designed, based on the G protein sequence of Korean IHNV (PRT strain, accession no. AY673684). The applicability of the RT-LAMP assay was evaluated by comparison with the nested RT-PCR assay using field samples.

\section{MATERIALS AND METHODS}

Viruses and cell culture. IHNV (PRT strain) was amplified in chinook salmon embryo (CHSE)-214 cells. Infectious pancreatic necrosis virus (IPNV) (VR-299, Jasper, Sp and Ab strains) and viral hemorrhagic septicemia virus (VHSV) were maintained in rainbow trout gonad (RTG)-2 cells with minimum essential medium-10 (supplemented with $10 \%$ fetal bovine serum, $200 \mathrm{mM}$ L-glutamine, $50 \mathrm{IU} \mathrm{ml}^{-1}$ penicillin and $50 \mathrm{mg} \mathrm{ml}^{-1}$ streptomycin) at $15^{\circ} \mathrm{C}$.

RNA extraction. To establish the optimal conditions for RT-LAMP, RNA was extracted from $500 \mu \mathrm{l}$ of supernatant from IHNV-infected cell cultures. For diagnosis, RNA was extracted from $100 \mathrm{mg}$ of fresh kidney and spleen taken from adult chum salmon and fry, homogenized in $750 \mu$ l of TRI Reagent ${ }^{\circledR}$ (Molecular Research Center), and incubated at room temperature for $5 \mathrm{~min}$. In both RNA extractrions, $200 \mu \mathrm{l}$ of chloroform was added to the homogenate and mixed by vortexing. The suspensions were incubated at room temperature for $10 \mathrm{~min}$ and centrifuged at $10000 \times g$ for $10 \mathrm{~min}$. The upper clear solution was transferred into a new $1.5 \mathrm{ml}$ microcentrifuge tube and the RNA precipitated using $200 \mu \mathrm{l}$ of $100 \%$ isopropanol on ice for $10 \mathrm{~min}$ before centrifugation at $10000 \times g$ for $10 \mathrm{~min}$. The RNA pellet was washed with $70 \%(\mathrm{v} / \mathrm{v})$ ethanol, centrifuged at $5000 \times g$ for $5 \mathrm{~min}$, then dried at $95^{\circ} \mathrm{C}$ in the incubator for $2 \mathrm{~min}$ or until the ethanol had evaporated. Diethylpyrocarbonate-treated water (Bioneer) was added to make a final concentration of $100 \mathrm{ng} \mathrm{ul}^{-1}$ and the RNA preparation was stored at $-20^{\circ} \mathrm{C}$ until use. RTLAMP and RT-PCR amplification were carried out using $2 \mu \mathrm{l}$ of this RNA as template.

Primers for RT-LAMP assay. RT-LAMP primers for IHNV were designed based on the published sequence of the G gene of IHNV (PRT strain, accession no. AY673684) using the software Primer Explorer version 4 (http://primerexplorer.jp/e/lamp4.0.0/index. html; Eiken Chemical). The forward inner primer (FIP) consisted of the complementary sequence of F1c (22 nt), a TTTT linker and the sense sequence of F2 (18 nt). The backward inner primer (BIP) contained a sense sequence of B1C (22 nt), a TTTT linker and the complementary sequence of B2 $(20 \mathrm{nt})$. The outer primers consisted of F3 (18 nt) and the complementary sequence of B3 (18 nt). To increase RT-LAMP sensitivity, loop primers were designed, which contained a loop forward primer (LF; $20 \mathrm{nt}$ ) and loop backward primer ( $\left(\mathrm{LB}_{;} 25 \mathrm{nt}\right)$. The details of the primers are listed in Table 1.

Optimization of RT-LAMP conditions. For optimization of the temperature and time conditions used for the RT-LAMP assay, reactions were carried out at $58,60,63$ or $65^{\circ} \mathrm{C}$ for 30,45 or $60 \mathrm{~min}$. The influence of $\mathrm{Mg}^{2+}$, betaine, dNTPs, Bst DNA polymerase and Avian myeloblastosis virus (AMV) reverse transcriptase was also tested. The LAMP reactions were performed in $25 \mu \mathrm{l}$ of total reaction mixture containing: $2 \mu \mathrm{M}$ each FIP and BIP, $0.2 \mu \mathrm{M}$ each F3 and B3, $2 \mu \mathrm{M}$ LF and LB primers, $1 \times$ thermopol-supplied reaction buffer, with 0.6 to $1.4 \mathrm{M}$ betaine (Sigma-Aldrich), 2 to $10 \mathrm{mM}$ $\mathrm{MgSO}_{4}$ (Sigma-Aldrich), 1 to $1.4 \mathrm{mM}$ dNTPs mix (Takara), 6 to $12 \mathrm{U}$ of Bst DNA polymerase (large fragment; New England Biolabs) and 0.25 to 0.75 U of AMV reverse transcriptase (Promega). Extracts from uninfected CHSE-214 cell cultures and reaction mixture without template were included as negative controls. RT-LAMP products were analyzed by $2 \%$ agarose gel electrophoresis. The time required to complete the LAMP reaction protocol was $\sim 60 \mathrm{~min}$.

Nested RT-PCR for IHNV detection. cDNA synthesis was conducted with $1 \mu \mathrm{g}$ of total RNA using an M-MLV reverse transcriptase kit (Bioneer) following the manufacturer's instructions. Five $\mu \mathrm{l}$ of cDNA were mixed with $20 \mu \mathrm{M}$ each of primers EXT-1 and EXT-2 (Table 2) (Troyer \& Kurath 2003) and transferred into an AccuPower ${ }^{\circledR}$ PCR PreMix tube (Bioneer); the reaction 
Table 1. Oligonucleotide primers used for reverse transcriptase loop-mediated isothermal amplification detection of infectious hematopoietic necrosis virus in chum salmon Oncorhynchus keta. BIP: backward inner primer; FIP: forward inner primer; LB: loop backward; LF: loop forward

\begin{tabular}{|lll|}
\hline Primer & Position & Sequence $\left(5^{\prime}{ }^{\prime}\right.$ 3' $\left.^{\prime}\right)$ \\
\hline F3 & $110-127$ & CAGCCAAACCGTCCAACC \\
B3 & $299-316$ & TCGTTCCGACCGACAGG \\
FIP & $179-200 /$ TTTT/128-145 & CAGAGTGCATCCTCGGGGAG/TTTT/CGACACCGCAAGCGAATC \\
BIP & $220-241 /$ TTTT/269-288 & ATGCCTCTCAACTGAGATGCCC/TTTT/ATGTGGGATAGGCAATCAGC \\
LF & $158-177$ & TGAAGAGCGGGTTTGACCAG \\
LB & $243-267$ & AGGATCTTCGATGATGAGAATAGGG \\
\hline
\end{tabular}

volume was made up to $20 \mu \mathrm{l}$ with DEPC-treated water (Bioneer). PCR amplification was conducted with an initial cycle at $95^{\circ} \mathrm{C}$ for 5 min followed by 30 cycles of $95^{\circ} \mathrm{C}$ for $30 \mathrm{~s}, 50^{\circ} \mathrm{C}$ for $30 \mathrm{~s}$ and $72^{\circ} \mathrm{C}$ for $60 \mathrm{~s}$. A final extension step was conducted at $72^{\circ} \mathrm{C}$ for $7 \mathrm{~min}$. The expected PCR product was $672 \mathrm{bp}$. A nested PCR amplification was carried out using $5 \mu \mathrm{l}$ of the first PCR products mixed with $20 \mu \mathrm{M}$ each of primers INT-1 and INT-2 (Table 2) (Troyer \& Kurath 2003), transferred into an AccuPower ${ }^{\circledR}$ PCR PreMix tube (Bioneer) and made up to a final volume of $20 \mu \mathrm{l}$ with DEPC-treated water. PCR reaction conditions were the same as described above. The expected PCR product was 462 bp in size.

Comparison of sensitivity between RT-LAMP and nested RT-PCR assays. The sensitivity of the 2 assays was determined using 10 -fold dilutions (100 pg to $0.001 \mathrm{fg}$ ) of RNA extracted from IHNV-infected CHSE214 cell cultures as template with the optimized conditions for the RT-LAMP and the nested RT-PCR as described above.

Specificity of the RT-LAMP assay. Specificity was tested using $100 \mathrm{ng}$ of RNA extracted from IPNV- (VR299, Ab, Jasper and Sp strains) and VHSV-infected RTG-2 cell cultures as non-target templates.

Evaluation of the RT-LAMP assay with field samples. The applicability of the RT-LAMP assay to detect IHNV was evaluated by comparing its ability to detect IHNV in field samples with that of nested RT-PCR. From 2006 to 2009, samples of adult wild chum salmon and artificially hatched fry were randomly collected from the Namdae River basin and hatcheries

Table 2. Oligonucleotide primers used for nested reverse transcriptase PCR detection of infectious hematopoietic necrosis virus in chum salmon Oncorhynchus keta

\begin{tabular}{|llll|}
\hline Primer & Orientation & Position & Sequence $\left(5^{\prime}-3^{\prime}\right)$ \\
\hline EXT-1 & Sense & $563-583$ & AGAGATCCCTACACCAGAGAC \\
EXT-2 & Antisense & $1235-1255$ & GGTGGTGTTGTTCCGTGCAA \\
INT-1 & Sense & $623-643$ & TCACCCTGCCAGACTCATTGG \\
INT-2 & Antisense & $1085-1105$ & ATAGATGGAGCCTTTGTCAT \\
\end{tabular}

at Yangyang City, located on the east coast of South Korea. The kidney and spleen from individual adult fish and pools of 5 fry were used for RNA extraction as described above. A total of 473 samples were analysed using RT-LAMP and nested RT-PCR as described above.

\section{RESULTS}

\section{Optimization of RT-LAMP reaction conditions}

When RT-LAMP was conducted at 58, 60, 63 and $65^{\circ} \mathrm{C}$ using $100 \mathrm{pg}$ of RNA, product was detected only at $63^{\circ} \mathrm{C}$ (Fig. 1). Moreover, RT-LAMP products were seen as multiple bands of different sizes on $2 \%$ agarose gel following run times of 30,45 or $60 \mathrm{~min}$ when using $10 \mathrm{ng}$ and $100 \mathrm{pg}$ of RNA (Fig. 2). Therefore, the optimal time was determined as $30 \mathrm{~min}$ for detecting IHNV by RT-LAMP in this study.

The influence of varying the concentrations of $\mathrm{MgSO}_{4}$, betaine, dNTPs, Bst DNA polymerase and AMV reverse transcriptase for RT-LAMP reaction were determined using $100 \mathrm{pg}$ of RNA as template. As the concentration of $\mathrm{MgSO}_{4}$ increased from 2 to $10 \mathrm{mM}$, the intensity of the LAMP products also increased and remained high from 6 to $10 \mathrm{mM} \mathrm{MgSO}_{4}$ (Fig. 3A). The optimal $\mathrm{MgSO}_{4}$ concentration was hence determined to be $6 \mathrm{mM}$. Under the optimal $\mathrm{MgSO}_{4}$ concentration, the RT-LAMP reactions were not affected by the different concentrations of betaine ( 0.6 to $1.4 \mathrm{M})$. Thus, the optimal concentration of betaine was determined to be $0.6 \mathrm{M}$ (Fig. 3B). RT-LAMP products were observed with all the tested concentrations of the dNTP mix (1 to $1.4 \mathrm{mM}$ ) (Fig. 3C). Therefore, the optimal dNTP concentration was determined to be $1 \mathrm{mM}$ for IHNV detection.

The effect of Bst DNA polymerase concentration was tested at $6,8,10$ and $12 \mathrm{U}$. The RT-LAMP products were observed at all concentrations tested (Fig. 4A). The AMV reverse transcrip- 


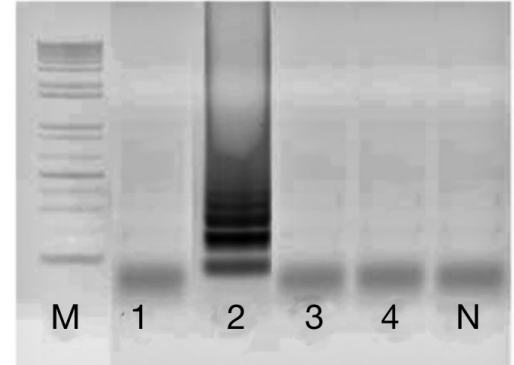

Fig. 1. Optimization of temperature for reverse transcriptase loop-mediated isothermal amplification (RT-LAMP) reactions using $100 \mathrm{pg}$ of RNA extracted from infectious hematopoietic necrosis virus (IHNV)-infected chinook salmon embryo (CHSE)-214 cells. Lane M: 100 bp DNA marker; Lanes 1 to 4: LAMP carried out at $65,63,60$ and $58^{\circ} \mathrm{C}$, respectively; Lane $\mathrm{N}$ : negative control

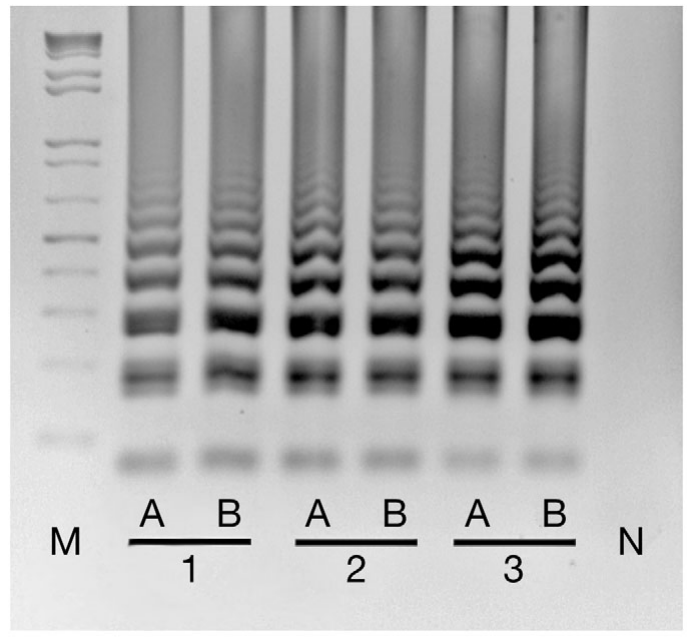

Fig. 2. Determination of RT-LAMP reaction time using (A) $10 \mathrm{ng}$ and (B) $100 \mathrm{pg}$ of RNA extracted from IHNV-infected CHSE-214 cells. Lane M: 100 bp DNA marker; Lanes 1 to 3: LAMP carried out for 30, 45 and 60 min, respectively; Lane N: negative control

tase concentration was also tested at $0.25,0.5$, and $0.75 \mathrm{U}$. The RT-LAMP products were observed at 0.25 and $0.5 \mathrm{U}$ AMV and their intensity decreased at $0.75 \mathrm{U}$ (Fig. 4B). Therefore, the optimal Bst DNA polymerase and AMV reverse transcriptase concentrations were determined to be 6 and $0.25 \mathrm{U}$, respectively.

\section{Comparison of RT-LAMP and nested RT-PCR limits of detection}

To compare the limits of detection, RT-LAMP and nested RT-PCR were carried out using 10-fold serial dilutions of RNA extracted from IHNV-infected CHSE214 cell cultures as template. The RT-LAMP was able
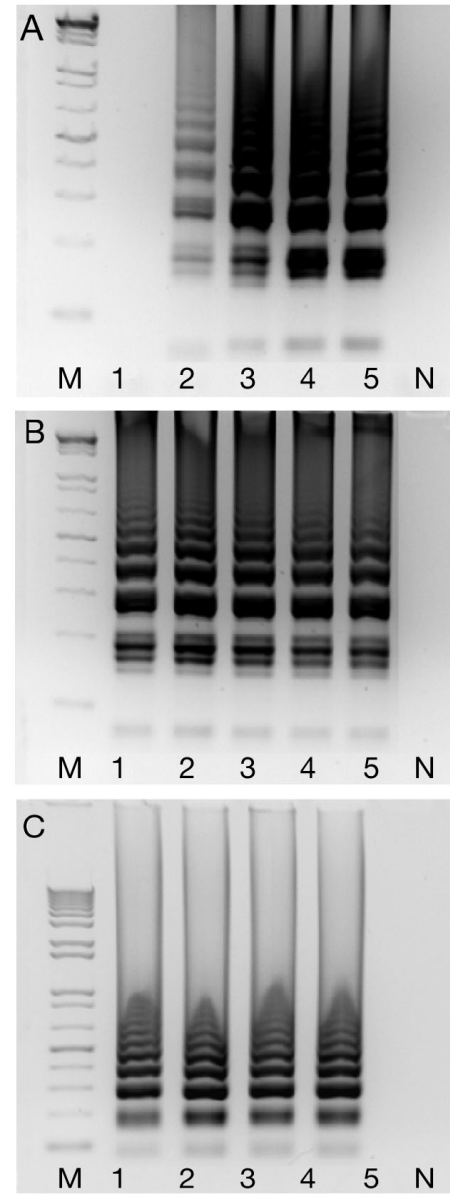

Fig. 3. Effects of $\mathrm{MgSO}_{4}$, betaine and dNTP concentrations on RT-LAMP reactions using $100 \mathrm{pg}$ of RNA extracted from IHNV-infected CHSE-214 cells. Lane M: 100 bp DNA marker; Lane N: negative control; (A) Lanes 1 to 5: $\mathrm{MgSO}_{4}$ concentrations of 2,4,6,8 and $10 \mathrm{mM}$, respectively. (B) Lanes 1 to 5: betaine concentrations of $0.6,0.8,1.0,1.2$ and $1.4 \mathrm{M}$, respectively. (C) Lanes 1 to 4: dNTP mix concentrations of 1, 1.2, 1.4 and $1.6 \mathrm{mM}$, respectively

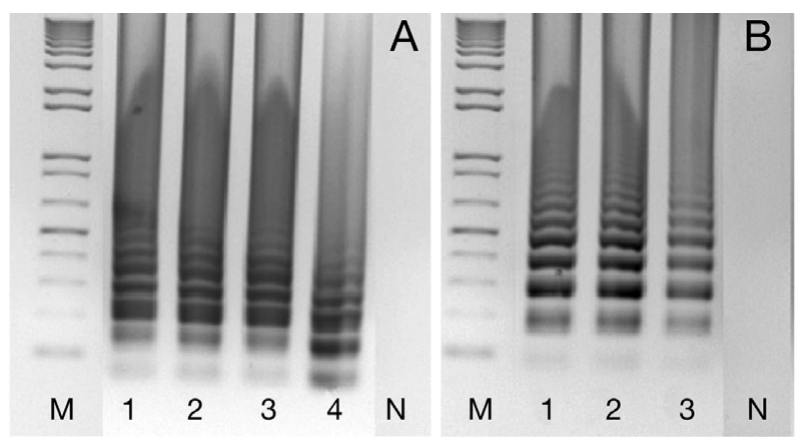

Fig. 4. Effects of Bst DNA polymerase and Avian myeloblastosis virus (AMV) reverse transcriptase concentrations for RT-LAMP reactions using $100 \mathrm{pg}$ of RNA extracted from IHNV-infected CHSE-214 cells. Lane M: 100 bp DNA marker; Lane N: negative control. (A) Lanes 1 to 4: Bst DNA polymerase concentrations of $6,8,10$ and $12 \mathrm{U}$, respectively. (B) Lanes 1 to 3: AMV reverse transcriptase concentrations of $0.25,0.5$ and $0.75 \mathrm{U}$, respectively 


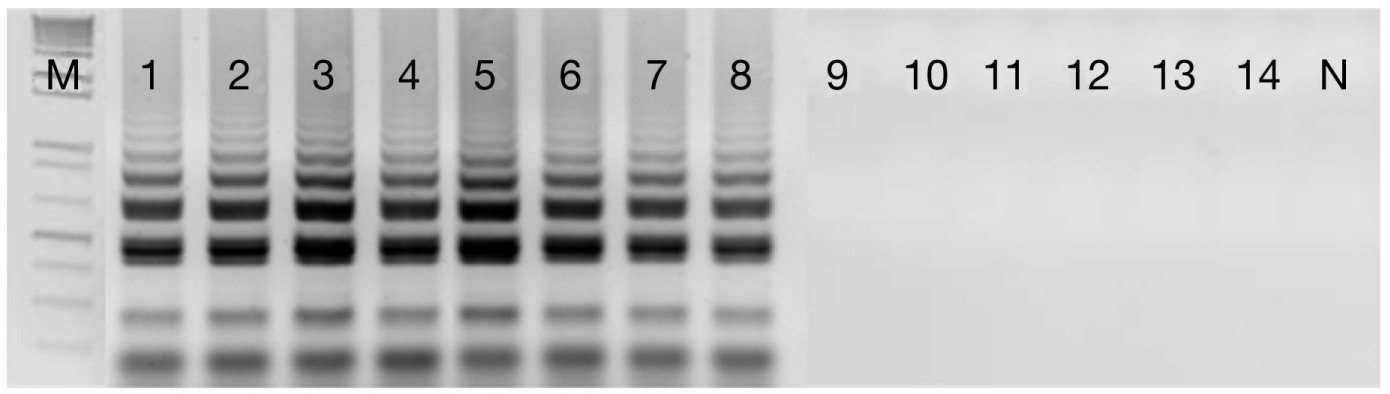

Fig. 5. Sensitivity and specificity of RT-LAMP for detection of IHNV in chum salmon Oncorhynchus keta. Lane M: 100 bp DNA marker; Lanes 1 to 9: 10-fold dilutions of RNA extracted from IHNV-infected CHSE-214 cells (100 pg to 0.001 fg); Lane 10: VHSVinfected RTG-2 cells; Lane 11: IPNV (VR-299 strain)-infected RTG-2 cells; Lane 12: IPNV (Sp strain)-infected RTG-2 cells; Lane 13: IPNV (Ab strain)-infected RTG-2 cells; Lane 14: IPNV (Jasper strain)-infected RTG-2 cells; Lane N: negative control

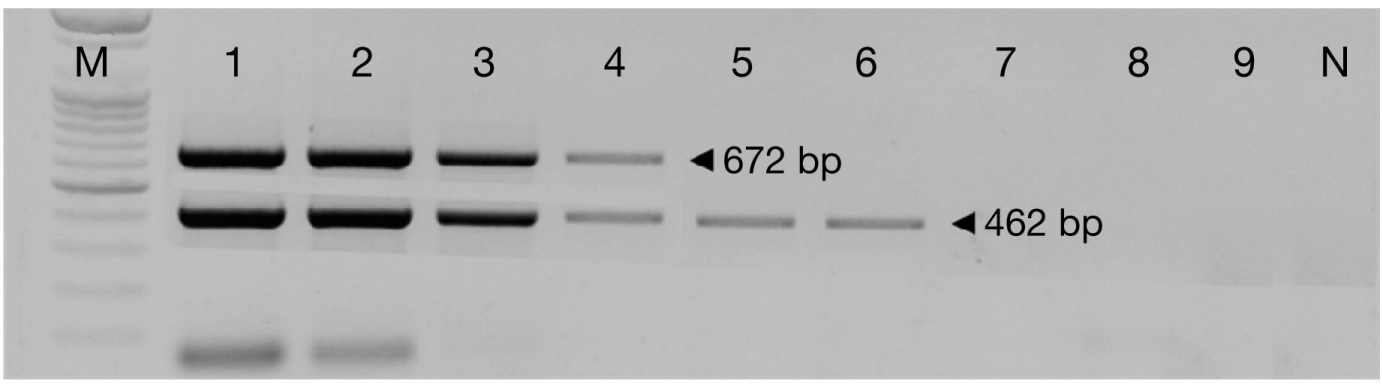

Fig. 6. Sensitivity of nested RT-PCR for detection of IHNV in chum salmon Oncorhynchus keta. Lane M: 100 bp DNA marker; Lanes 1 to 9: 10-fold dilutions of RNA extracted from IHNV-infected CHSE-214 cells (100 pg to $0.001 \mathrm{fg}$ ); Lane N: negative control

to detect template at $0.01 \mathrm{fg}$ RNA (Fig. 5, Lane 8), whereas the nested RT-PCR was able to detect template at $1.0 \mathrm{fg}$ (Fig. 6, Lane 6). Thus, the sensitivity of the LAMP method was 100 times higher than that of nested RT-PCR in this study.

\section{Specificity of RT-LAMP detection}

RNA from 2 other salmonid viral pathogens (IPNV and VHSV) was tested to assess the specificity of RTLAMP. No amplification was observed (Fig. 5, Lanes 10 to 14$)$.

\section{Evaluation of RT-LAMP method with field samples of chum salmon}

A total of 473 chum salmon samples were randomly collected from Namdae River, Yangyang City, South Korea from 2006 to 2009, including 113 pools of 5 artificially hatched fry and 360 wild adult chum salmon. The IHNV detection rates from the tested samples are summarized in Table 3. Out of 473 samples, 191 $(40.38 \%)$ were IHNV-positive with the RT-LAMP assay, including 76 pooled fry samples and 115 adult samples (Fig. 7). By nested RT-PCR assay, 162 (34.25\%; 53 pooled fry samples and 109 adult samples) of the 473 samples were IHNV-positive (Fig. 8).

\section{DISCUSSION}

Fish disease diagnosis is based on the appearance of clinical signs with confirmation by isolation and identification of the aetiological agent. To facilitate disease

Table 3. Comparison of the prevalence of infectious hematopoietic necrosis virus (IHNV) in chum salmon Oncorhynchus keta by nested reverse trancriptase (RT)-PCR and RT loop-mediated isothermal amplification (RT-LAMP)

\begin{tabular}{|ccccc|}
\hline \multirow{2}{*}{ Year } & \multirow{2}{*}{$\begin{array}{c}\text { Sample } \\
\text { type }\end{array}$} & \multirow{2}{*}{$\begin{array}{c}\text { Number } \\
\text { of samples }\end{array}$} & Nested RT-PCR & RT-LAMP \\
\cline { 4 - 5 } 2006 & Adult & 80 & $23(28.75 \%)$ & $23(28.75 \%)$ \\
2007 & Fry & 32 & $21(65.63 \%)$ & $32(100.00 \%)$ \\
& Adult & 80 & $3(3.75 \%)$ & $9(11.25 \%)$ \\
2008 & Fry & 32 & $23(71.88 \%)$ & $32(100.00 \%)$ \\
& Adult & 80 & $17(21.25 \%)$ & $17(21.25 \%)$ \\
2009 & Fry & 49 & $9(18.37 \%)$ & $12(24.49 \%)$ \\
& Adult & 120 & $66(55.00 \%)$ & $66(55.00 \%)$ \\
Total & & 473 & $162(34.25 \%)$ & $191(40.38 \%)$ \\
& & & & \\
\hline
\end{tabular}




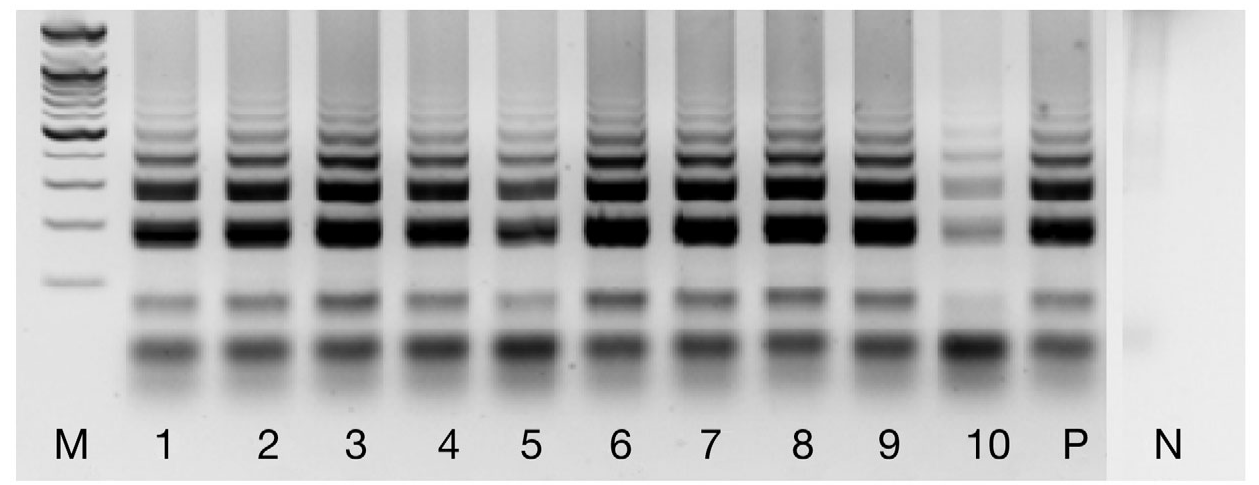

Fig. 7. Detection of IHNV in chum salmon Oncorhynchus keta field samples by RT-LAMP. Lane M: 100 bp DNA marker; Lanes 1 to 10: pooled fry samples; Lane P: 10 fg of RNA extracted from IHNV-infected CHSE-214 cells; Lane N: negative control

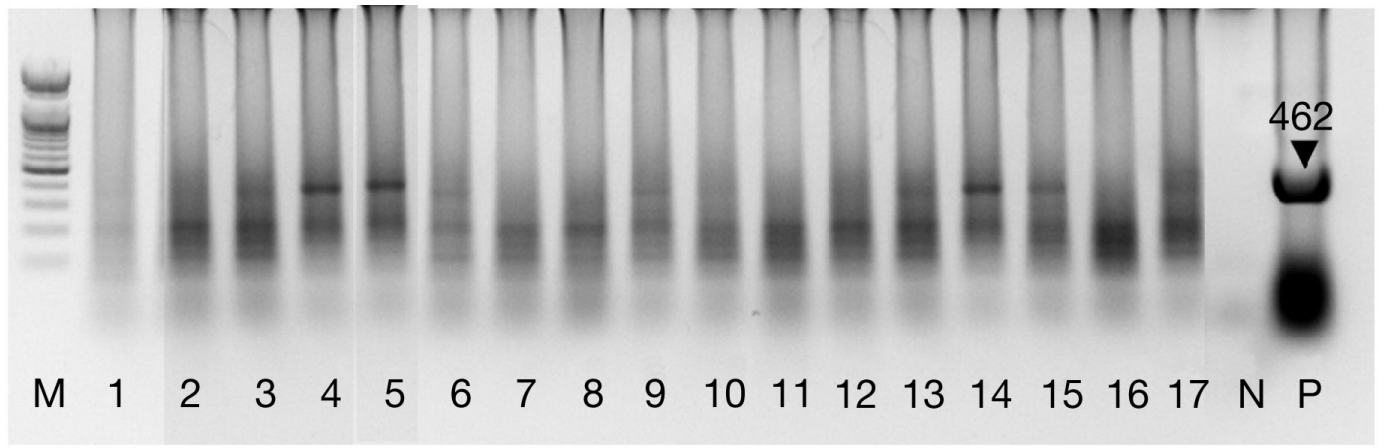

Fig. 8. Detection of IHNV in chum salmon Oncorhynchus keta field samples by nested RT-PCR. Lane M: 100 bp DNA marker; Lanes 1 to 17: pooled fry samples; Lane N: negative control; Lane P: $10 \mathrm{fg}$ of RNA extracted from IHNV-infected CHSE-214 cells

control and management the use of rapid and sensitive methods is desirable. LAMP is a novel method of DNA amplification that has already been applied to detection of several pathogens in aquaculture (Savan et al. 2005). These include IHNV (Gunimaladevi et al. 2005, McCarthy et al. 2006), infectious salmon anemia virus (ISAV) (McCarthy et al. 2006), VHSV (Soliman \& ElMatbouli 2006), spring viraemia of carp virus (SVCV) (Liu et al. 2008), IPNV (Soliman et al. 2009), turbot reddish body iridovirus (TRBIV) (Zhang et al. 2009), white spot syndrome virus (WSSV) (Kono et al. 2004), koi herpesvirus (KHV) (Gunimaladevi et al. 2004), yellow head virus (YHV) (Mekata et al. 2006) and Taura syndrome virus (TSV) (Kiatpathomchai et al. 2007). According to these studies, the sensitivity of the LAMP assay is higher than the conventional PCR assay.

In the present study, the RT-LAMP assay was developed for the detection of IHNV in chum salmon Oncorhynchus keta. Three sets of LAMP primers were able to amplify a $206 \mathrm{bp}$ sequence of the G gene of IHNV PRT strain under optimized conditions at $63^{\circ} \mathrm{C}$ for $30 \mathrm{~min}$. The $\mathrm{MgSO}_{4}$, betaine, dNTPs, DNA polymerase and reverse transcriptase concentrations were optimized as these can influence RT-LAMP reactions as previously described (Notomi et al. 2000, Fukuta et al. 2003, Nie 2005). At least $4 \mathrm{mM} \mathrm{MgSO}_{4}$ was needed for a visible reaction and 6 to $10 \mathrm{mM}$ produced similar optimal results. The presence of 0.5 to 1.5 $\mathrm{M}$ betaine could elevate the overall rate of the reaction and also increase target selectivity with a significant reduction in amplification of inappropriate sequences as previously reported by Notomi et al. (2000). With betaine, the amplification of short target fragments $(<300 \mathrm{bp})$ was not affected, but non-specific amplification, as reported by Baskaran et al. (1996), was reduced. The levels of Bst DNA polymerase (6 U) and AMV reverse transcriptase (0.25 U) were also optimized for use under optimal $\mathrm{MgSO}_{4}$, betaine and dNTPs concentrations.

The RT-LAMP technique for detecting IHNV was previously reported in Japan (Gunimaladevi et al. 2005). In their experiment, IHNV-specific LAMP 
primers were based on the G protein of the WRAC strain (accession no. L40883) isolated from chinook salmon Oncorhynchus tschawytscha belonging to the American genogroup M (Enzmann et al. 2005). However, all of the Korean IHNV isolates belong to the JRt genogroup (Kim et al. 2007) and there is no report on the occurrence of the $M$ genogroup in Korea at the present time. Thus, we selected the PRT strain for designing RT-LAMP primers to detect the G protein of IHNV from chum salmon in Korea. This strain was isolated from masu salmon O. masou in Korea (Park et al. 1993). These loop primer sets can hybridize to the stem-loop forms and hence the present RT-LAMP assay can recognize 8 regions of the G gene of IHNV with a set of 6 primers. The reaction could be completed within $30 \mathrm{~min}$ at $63^{\circ} \mathrm{C}$ in the present study, whereas conventional RT-PCR required 2.5 to $3 \mathrm{~h}$ to complete. Moreover, RT-LAMP detected as little as $0.01 \mathrm{fg}$ of RNA extracted from IHNV-infected CHSE214 cells, compared with $1.0 \mathrm{fg}$ for nested RT-PCR. No cross-amplification with IPNV and VHSV was observed, all of which indicated that this RT-LAMP assay can specifically detect IHNV in Korea. In addition, the nested RT-PCR assay requires an additional step for completing the reaction, whereas RT-LAMP requires only one step, limiting the risk of cross-contamination. The RT-LAMP assay is simple and easy to perform and only requires the use of a conventional laboratory water bath or a heating block.

The applicability of the IHNV RT-LAMP assay was evaluated with field samples and the results were compared with those obtained using a nested RT-PCR. The results showed that 191 out of 473 samples $(40.38 \%)$ were IHNV-positive using RT-LAMP, whereas the detection rate decreased when using nested RT-PCR $(34.25 \% ; 162$ of 473$)$. These results indicate that RTLAMP would be more suitable than the nested RT-PCR assay for early field diagnosis and/or surveillance programs because it is more sensitive, does not require expensive equipment such as a thermal cycler and is less time-consuming.

IHNV causes significant mortalities both in wild and cultured salmonids (Wolf 1988, Bootland \& Leong 1999, Williams et al. 1999). Although rainbow trout are known to be the most susceptible fish species, several other salmonid species are also susceptible to IHNV infection (Wolf 1988, Winton 1991, Bootland \& Leong 1999), with fry being more susceptible than adult fish. Surviving fry or adults can become sub-clinical carriers (St-Hilaire et al. 2001) and early detection of sub-clinical infection is very important for preventing the spread of IHNV.

In conclusion, considering the prevalence and economic losses due to IHNV infection in salmonids, a simple, cheap, rapid, sensitive and specific method is desirable for early diagnosis in fish farms. The RT-
LAMP assay described here fulfills these requirements, at least for the Korean strains of IHNV. It could be used as a routine assay for targeted surveillance for early detection of IHNV infection in salmonid farms, especially where expensive diagnostic instruments are not available.

Acknowledgements. This work was supported by a grant from the National Research Foundation of Korea (20090087136). The authors thank K. B. Seong and C. H. Lee (Cold Water Fish Research Center, Yangyang, Korea) for their help in collecting fish samples.

\section{LITERATURE CITED}

Baskaran N, Kpal RP, Bhargava AK, Glynn MW, Bale A, Weissman SM (1996) Uniform amplification of a mixture of deoxyribonucleic acids with varying GC content. Genome Res 6:633-638

Baudin-Laurencin F (1987) IHN in France. Bull Eur Assoc Fish Pathol 7:104

Bootland LM, Leong JC (1999) Infectious hematopoietic necrosis virus. In: Woo PTK, Bruno DW (eds) Fish diseases and disorders, Vol 3. Viral, bacterial and fungal infection. CAB International, New York, NY, p 57-121

Bovo G, Giorgetti G, Jsrgensen PEV, Olesen NJ (1987) Infectious haematopoietic necrosis: first detection in Italy. Bull Eur Assoc Fish Pathol 7:124

Enzmann PJ, Dangschat H, Feneis B, Schrnit D, Wizigmann G, Schlotfeldt HJ (1992) Demonstration of IHN virus in Germany. Bull Eur Assoc Fish Pathol 12:185

Enzmann PJ, Kurath G, Fichtner D, Bergmann SM (2005) Infectious hematopoietic necrosis virus: monophyletic origin of European isolates from North American Genogroup M. Dis Aquat Org 66:187-195

Fukuta S, Iida T, Mizukami Y, Ishida A, Ueda J, Kanbe M, Ishimoto Y (2003) Detection of Japanese yam mosaic virus by RT-LAMP. Arch Virol 148:1713-1720

Garver KA, Troyer RM, Kurath G (2003) Two distinct phylogenetic clades of infectious hematopoietic necrosis virus overlap within the Columbia River basin. Dis Aquat Org 55:187-203

Gunimaladevi I, Kono T, Venugopal MN, Sakai M (2004) Detection of koi herpesvirus in common carp, Cyprinus carpio L., by loop-mediated isothermal amplification. J Fish Dis 27:583-589

Gunimaladevi I, Kono T, LaPatra SE, Sakai M (2005) A loop mediated isothermal amplification (LAMP) method for detection of infectious hematopoietic necrosis virus (IHNV) in rainbow trout (Oncorhynchus mykiss). Arch Virol 150:899-909

Kiatpathomchai W, Jareonram W, Jitrapakdee S, Flegel TW (2007) Rapid and sensitive detection of Taura syndrome virus by reverse transcription loop-mediated isothermal amplification. J Virol Methods 146:125-128

Kim SJ, Lee EY, Oh MJ, Choi TJ (2001) Comparison of IHNV detection limits by IMS-RT-PCR, western blot ELISA. J Fish Sci Technol 4:32-38

Kim KH, Kim YJ, Jung SJ, Jung TS, Oh MJ (2003) Isolation and characterization of infectious hematopoietic necrosis virus causing high mortality in rainbow trout Oncorhynchus mykiss. J Fish Pathol 16:81-90 (in Korean with English Abstract)

Kim WS, Oh MJ, Nishizawa T, Park JW, Kurath G, Yoshimizu $M$ (2007) Genotyping of Korean isolates of infectious 
hematopoietic necrosis virus (IHNV) based on the glycoprotein gene. Arch Virol 152:2119-2124

Kono T, Savan R, Sakai M, Itami T (2004) Detection of white spot syndrome virus in shrimp by loop-mediated isothermal amplification. J Virol Methods 115:59-65

Kurath G, Ahern KG, Pearson GD, Leong JC (1985) Molecular cloning of the six mRNA species of infectious hematopoietic necrosis virus, a fish rhabdovirus and gene order determination by R-loop mapping. J Virol 53:469-476

Kurath G, Garver KA, Troyer RM, Emmenegger EJ, EinerJensen K, Anderson ED (2003) Phylogeography of infectious hematopoietic necrosis virus in North America. J Gen Virol 84:803-814

Liu Z, Teng Y, Xie X, Li H and others (2008) Development and evaluation of a one-step loop-mediated isothermal amplification for detection of spring viraemia of carp virus. J Appl Microbiol 105:1220-1226

McCarthy EL, Egeler TJ, Bickerstaff LE, Pereira da Cunha M, Millard PJ (2006) Detection identification of IHN and ISA viruses by isothermal DNA amplification in microcapillary tubes. Anal Bioanal Chem 386:1975-1984

Mekata T, Kono T, Savan R, Sakai M, Kasornchandra J, Yoshida T, Itami T (2006) Detection of yellow head virus in shrimp by loop-mediated isothermal amplification (LAMP). J Virol Methods 135:151-156

Morzunov SP, Winton JR, Nichol ST (1995) The complete genome structure and phylogenetic relationship of infectious hematopoietic necrosis virus. Virus Res 38:175-192

Nie X (2005) Reverse transcriptase loop-mediated isothermal amplification of DNA for detection of Potato virus $Y$. Plant Dis 89:605-610

Nishizawa T, Kinoshita S, Kim WS, Higashi S, Yoshimizu M (2006) Nucleotide diversity of Japanese isolates of infectious hematopoietic necrosis virus (IHNV) based on the glycoprotein gene. Dis Aquat Org 71:267-272

Notomi T, Okayama H, Masubuchi H, Yonekawa T, Watanabe K, Amino N, Hase T (2000) Loop-mediated isothermal amplification of DNA. Nucleic Acids Res 28:e63

Park MA, Sohn SG, Lee SD, Chun SK, Park JW, Fryer JL, Hah

Editorial responsibility: Mark Crane, Geelong, Victoria, Australia
YC (1993) Infectious haematopoietic necrosis virus from salmonids cultured in Korea. J Fish Dis 16:471-478

Rucker RR, Whipple WJ, Parvin JR, Evans CA (1953) A contagious disease of salmon possibly of virus origin. US Fish Wildl Serv Fish Bull 54:35-46

Sano T (1976) Viral diseases of cultured fish in Japan. Fish Pathol 10:221-226

Savan R, Kono T, Itam T, Sakai M (2005) Loop-mediated isothermal amplification: an emerging technology for detection of fish shellfish pathogens. J Fish Dis 28: 573-581

Soliman H, El-Matbouli M (2006) Reverse transcription loopmediated isothermal amplification (RT-LAMP) for rapid detection for viral hemorrhagic septicaemia virus (VHS). Vet Microbiol 114:205-213

Soliman H, Midtlyng PJ, El-Matbouli M (2009) Sensitive and rapid detection of infectious pancreatic necrosis virus by reverse transcription loop mediated isothermal amplification. J Virol Methods 158:77-83

St-Hilaire S, Ribble C, Traxler G, Davies T, Kent ML (2001) Evidence for a carrier state of infectious hematopoietic necrosis virus in chinook salmon Oncorhynchus tshawytscha. Dis Aquat Org 46:173-179

Troyer RM, Kurath G (2003) Molecular epidemiology of infectious hematopoietic necrosis virus reveals complex virus traffic and evolution within southern Idaho aquaculture. Dis Aquat Org 55:175-185

- Williams K, Blake S, Sweeney A, Singer JT, Nicholson BL (1999) Multiplex reverse transcriptase PCR assay for simultaneous detection of three fish viruses. J Clin Microbiol 37:4139-4141

> Winton JR (1991) Recent advances in detection and control of infectious hematopoietic necrosis virus. Annu Rev Fish Dis 1:83-93

Wolf K (1988) Fish viruses and fish viral diseases. Cornell University, Ithaca, NY

> Zhang Q, Shi C, Huang J, Jia K, Chen X, Liu H (2009) Rapid diagnosis of turbot reddish body iridovirus in turbot using the loop-mediated isothermal amplification method. J Virol Methods 158:18-23

Submitted: May 14, 2010; Accepted: November 8, 2010 Proofs received from author(s): February 28, 2011 